\title{
Filsafat Ilmu Sebagai Dasar Dan Arah Pengembangan Ilmu Hukum Di Indonesia
}

\author{
Oleh : Mila Karmila Adi \\ Dosen FH UII Yogyakarta \\ e-mail:mila_alam@fh.uii.ac.id
}

\begin{abstract}
The development of Legal Science in Indonesia has disappointed the society, since the products of law give no good benefit impact even make more difficulties without any problem solving as the main point of the products. It seems that Legal Science in Indonesia is stuck between Continental and Anglo Legal Systems. Science Philosophy is the right tool to give the basic and direction to the development of legal Science in Indonesia, because the aspects of Science Philosophy, as Knower, Knowing, and Knowledge, will lead the Legal Science in Indonesia developed in the right track. The Legal Science in Indonesia should be based on the religious, humanity, united in diversity, democracy, and social justice, as the basic philosophy of Indonesian nation.
\end{abstract}

Keywords: filsafat ilmu, ilmu hukum

\section{Pendahuluan}

Kekecewaan dan ketidakpuasan atas produk-produk hukum yang berlaku saat ini seringkali muncul dalam pemberitaan di media cetak maupun elektronik, bahkan sampai pada pembicaraan di kalangan masyarakat umum. Produk-produk hukum berupa peraturan perundangan, peraturan kebijakan, keputusan atau ketetapan, sampai surat edaran, dianggap tidak dapat menyelesaikan masalah bahkan seringkali menimbulkan masalah baru.

Kekecewaan dan ketidakpuasan ini terutama ditujukan kepada para pembuat hukum dan penegak hukum yang mempunyai kewajiban untuk mendeskripsikan dan menjalankan hukum dalam kehidupan sehari-hari. Hukum dalam kehidupan masyarakat dapat dirasakan secara langsung melalui produk-produk hukum maupun sikap tindak para aktor hukum, sehingga hukum tidak hanya berarti peraturan perundangan, akan tetapi 
juga institusi/lembaga dan norma-norma yang berkembang dalam pergaulan hidup. ${ }^{1}$

Perilaku para aktor hukum memang merupakan suatu hal yang fenomenal, karena tingkah laku para aktor tersebut merupakan konsekuensi-konsekuensi dari sejumlah pandangan yang bekerja di kepala manusia. ${ }^{2}$ Muncul pertanyaan yang mengarah pada bagaimana sebenarnya dunia ilmu hukum itu, sehingga memunculkan aktor-aktor hukum yang demikian? Pertanyaan ini bersifat menggugat hukum sebagai suatu ilmu, apakah hukum dapat dipelajari secara objektif sebagai suatu subjek? $?^{3}$ Apakah hukum itu bukan hanya merupakan produk politik dari para pemegang kekuasaan, sehingga hukum tidaklah dapat dipelajari dan tidak membutuhkan filosofi tertentu yang mendasarinya?

Perdebatan hukum sebagai suatu ilmu atau bukan memang telah berakhir, akan tetapi ilmu hukum sebagai bagian dari ilmu praktikal yang bersifat normologikal ${ }^{4}$, seolah-olah tidak lagi dapat menjadi pedoman, arahan, dan alat kontrol, bagi hukum praktikal secara rasional. Sebagai Ilmu Praktikal, hukum juga dimaksudkan untuk mempelajari cara menemukan dan menawarkan alternatif penyelesaian masalah konkrit ${ }^{5}$. Ketidakmampuan Ilmu Hukum untuk melaksanakan fungsinya tersebut dapat menjadi suatu bahan kajian dari filsafat sebagai ilmu kritis ${ }^{6}$ untuk mencari kebenaran yang sesungguhnya dari Ilmu Hukum, sehingga Hukum dapat memenuhi fungsinya sebagai suatu ilmu.

\footnotetext{
${ }^{1}$ Lihat L.J. van Apeldoorn, Pengantar Ilmu Hukum, Cetakan Keduapuluhenam, Pradnya Paramita, Jakarta, 1996, hlm.1-7.

${ }^{2}$ Dalam sosiologi, tonggak aliran teori ini diletakkan oleh Max Weber dengan teori "verstehen" (penghayatan, pemahaman interpretatif) dalam upaya memahami tingkah laku manusia. Lihat Esmi Warassih, "Metodologi Penelitian Hukum", makalah tanpa tahun.

${ }^{3}$ Lihat Archie J. Bahm, "What is Science (Apa itu Ilmu)", makalah tanpa tahun, hlm.5.

${ }^{4}$ Hukum bersifat normologikal berarti berintikan relasi imputative; menautkan tanggungjawab pada subyek tertentu karena perilaku seseorang. Dipengaruhi kemauan manusia. Kausalitas non-deterministik (Jika A, seyogianya B), dalam B. Arief Sidharta, "Ilmu, Teori dan Filsafat Hukum", dalam bahan kuliah Program Doktor (S-3) Ilmu Hukum, Fakultas Hukum Universitas Islam Indonesia, 2007, hlm.1.

${ }^{5}$ Ibid., hlm.3.

${ }^{6}$ Franz Magnis Suseno, Filsafat sebagai Ilmu Kritis, Cetakan Pertama, Kanisius, Yogyakarta, 1992, hlm.20.
} 
Dengan demikian adalah sangat penting untuk mengetahui dan menelaah bagaimana Filsafat Ilmu mendasari dan mengarahkan pengembangan Ilmu Hukum di Indonesia, sehingga hukum di Indonesia tidak hanya kalimat indah di atas kertas atau bahkan menjadi alat politik belaka. Tulisan ini menganalisis secara deskriptif kualitatif, sehingga penjelasannya dilakukan dengan kata-kata, tanpa tabel atau angka-angka.

\section{Hukum sebagai suatu Ilmu}

Hukum sebagai suatu ilmu pada dasarnya merupakan suatu objek pembicaraan yang cukup unik sekaligus rumit, bahkan sampai saat ini belum ada kesatuan pendapat tentang pengertian apa itu hukum.

Pendefinisian tentang hukum memang diperlukan untuk mengetahui apa yang akan dipelajari lebih lanjut tentang hukum itu sendiri, menunjukkan jalan (open the way), ke arah mana ia akan berjalan. ${ }^{7}$ Akan tetapi karena definisi hukum itu sendiri sulit untuk disatukan, bahkan menurut Kant lebih dari 150 tahun yang lalu: „Noch suchen die Juristen eine Definition zu ihrem Begriffe von Recht", hal ini akan merugikan apabila definisi hukum yang dianut memberi kesan yang tidak tepat bagi mereka yang baru mempelajarinya. ${ }^{8}$

Apa artinya hukum, dapat diketahui dengan tiga jalan?:

1. Melalui pengalaman sehari-hari, kita mengetahui bahwa hukum mengatur hidup bersama kita.

2. Melalui studi tentang hukum, kita memperoleh suatu pengetahuan yang terperinci tentang peraturan-peraturan hukum yang berlaku dalam negara kita.

3. Melalui filsafat hukum kita berusaha untuk mengerti makna hukum dalam rangka suatu pandangan yang menyeluruh tentang kehidupan kita.

Hukum sebagai disiplin ilmu mengarahkan sasaran studinya terhadap kaidah atau norma yang menghasilkan ilmu tentang kaidah hukum (norm wissenschaft), terhadap pengertian-pengertian dalam hukum yang menghasilkan ilmu tentang pengertian hukum (begriffen wissenschaft), dan

${ }^{7}$ Lili Rasjidi, Filsafat Hukum; Apakah Hukum itu?, Cetakan Keenam, Remaja Rosdakarya, Bandung, 1993, hlm.29.

${ }^{8}$ L.J. van Apeldoorn, Op.Cit., hlm.1. hlm.15.

${ }^{9}$ Theo Huijbers, Filsafat Hukum, Cetakan Kesembilan, Kanisius, Yogyakarta, 2003, 
terhadap kenyataan-kenyataan dalam hukum yang menghasilkan ilmu tentang kenyataan hukum (sein wissenschaft). ${ }^{10}$

Perdebatan juga berkembang di sekitar apakah Ilmu Hukum itu termasuk ke dalam jajaran ilmu-ilmu sosial atau sebagai ilmu kemanusiaan karena bersifat normatif. ${ }^{11}$

Ilmu Hukum sebagai bagian ilmu sosial, karena menghadapi manusiamanusia, bukan "benda-benda" sebagai objeknya. Yang membedakan manusia dengan hal-hal yang lain ialah bahwa manusia dapat melakukan perbuatan. Ia melakukan perbuatan dengan maksud tertentu, artinya untuk mencapai suatu tujuan tertentu. Untuk mencapai tujuan tersebut ia memikirkan sarana-sarananya. Ia melakukan tinjauan kembali atas tujuan-tujuan yang hendak dicapainya untuk melengkapinya. Ia dapat melakukan kesalahan dalam mengubah-ubah sarana-tujuan tersebut. Pandangannya mengenai kenyataan mengandaikan penafsirannya mengenai kenyataan. Unsur-unsur kimia, bintang-bintang serta tanamantanaman tidak menghiraukan penyelidikan yang dilakukan oleh ilmuilmu terhadapnya. Di dalam sejarah dan masyarakat manusia yang bersangkutan dalam melakukan perbuatan-perbuatan mendasarkan diri pada kaidah-kaidah, ketentuan-ketentuan, nilai-nilai yang berlaku. ${ }^{12}$

Sedangkan apabila Ilmu Hukum termasuk dalam ilmu kemanusiaan, sebagaimana dikemukakan oleh B.Arief Sidharta ${ }^{13}$, Ilmu Hukum termasuk dalam kelompok Ilmu Praktis. Ilmu Hukum menempati kedudukan istimewa dalam klasifikasi ilmu, bukan hanya karena mempunyai sejarah yang panjang yang memapankannya dibandingkan dengan ilmu lainnya, tetapi juga karena sifatnya sebagai Ilmu Normatif dan dampak langsungnya terhadap kehidupam manusia dan masyarakat yang terbawa oleh sifat problematiknya (masalah mendesak yang inheren dalam kehidupan sehari-hari manusia) yang telah memunculkan dan membimbing pengembanan serta pengembangannya. ${ }^{14}$.

\footnotetext{
${ }^{10}$ Moch. Fatich, Aspek Ontologis, Epistemologis Dan Aksiologis Dari Bangunan Ilmu Hukum,
index.php?option=com_content\&task=view\&id=44\&Itemid=6 didownload pada Senin 31 Maret 2008, pukul 11.45 wib.

${ }^{11}$ Abdurrahman, Op.Cit., hlm.1.

12 Beerling, Kwee, Mooij van Peursen, Pengantar Filsafat Ilmu, Cetakan Ketiga, diterjemahkan oleh Soejono Soemargono, Tiara Wacana Yogya, Yogyakarta, 1990, hlm.139.

${ }^{13}$ B.Arief Sidharta, "Posisi Ilmu Hukum dalam Klasifikasi Ilmu", makalah tanpa tahun, hlm.7

${ }^{14}$ Ibid.
} 
Ilmu Hukum yang termasuk dalam Ilmu Praktis ${ }^{15}$ itu menyandang sifat khas tersendiri. Selain karena alasan yang telah dikemukakan di atas, juga objek telaahnya berkenaan dengan tuntutan berperilaku dengan cara tertentu yang kepatuhannya tidak sepenuhnya tergantung pada kehendak bebas yang bersangkutan, melainkan dapat dipaksakan oleh kekuasaan publik. Pada masa sekarang kedudukan Ilmu Hukum lebih khusus lagi, karena objek telaahnya bukan hanya hukum sebagaimana yang biasa dipahami secara tradisional, tugasnya sudah lebih banyak terarah pada penciptaan hukum baru yang diperlukan untuk mengakomodasi timbulnya berbagai hubungan kemasyarakatan yang baru. ${ }^{16}$

Setiap perluasan kemungkinan penerapan dan setiap penjajagan (=exploration) jangkauan penerapan baru, tentu didasarkan atas akibat suatu teori baru. Dalam hal ini sebuah teori semakin lama semakin tersusun secara sistematik, dan kemudian atas dasar teori tadi, penerapanpenerapan yang tidak serupa menjurus ke arah suatu perspektif yang ditinjau secara teoretik merupakan kesatuan. ${ }^{17}$

Ilmu Hukum sebagai bagian dari ilmu pengetahuan juga mengalami pasang surut perkembangan, mulai dari zaman purba (pra Socrates, Yunani, Romawi), Abad Pertengahan, Renaissance, Zaman Baru, hingga pada zaman modern, mulai dari Aliran Hukum Alam, hingga Aliran Hukum Pragmatis Amerika. ${ }^{18}$ Perkembangan Ilmu Hukum sampai saat ini ternyata tidak mampu untuk menyatukan pendapat tentang perumusan apa itu "Ilmu Hukum". Hal ini, menurut Curzon"19, ada 3 problem pokok yang akan timbul sehubungan dengan pembuatan rumusan tentang apa sebenarnya jurisprudence atau Ilmu Hukum itu, yaitu:

(1) Definition, by its nature, imposses theoretical boundaries on subject matter. But the area of observation and investigation of jurisprudence cannot be confined with case, in recent years, for example, it has embraced consideration of information theory, cybernetics and legal data retrieval by computer. A restrictive definition is of little value in an expanding subject area.

${ }^{15}$ Istilah "ilmu praktis" juga disamakan dengan istilah "ilmu terapan". Lihat Beerling, Kwee, Mooij Van Peursen, Op.Cit., hlm. 127.

${ }^{16}$ Disarikan dari B.Arief Sidharta, Posisi..., Loc.Cit.

${ }^{17}$ Beerling, Kwee, Mooij Van Peursen, Op.Cit., hlm. 126.

${ }^{18}$ Lili Rasjidi dan I.B. Wyasa Putra, Hukum Sebagai Suatu Sistem, Cetakan Pertama, PT.Remaja Rosdakarya, Bandung, 1993, hlm.24.

${ }^{19}$ Curzon dalam Abdurrahman, Op.Cit.,hlm.23. 
(2) The inter-diciplinary nature of jurisprudence suggest that it may be no more than a mode of inquiry, a method of philosophical investigation stemming from interest in legal phenomena and, as such, defying the categories of definition applicable to restriced methodologies of thought.

(3) The very of nature of words makes definition no more than approximation, it is contended, so that to attempt to define "juriprudence" is to make no more than a calculated guess as to its essential nature.

Ilmu Hukum memberikan kontribusi pada penemuan hukum, dan dengan itu juga pada pembentukan hukum. Orang "menemukan", menetapkan, apa yang dalam situasi konkrit yang akan diuraikan lebih jauh harus dipandang sebagai hukum yang berlaku yang dapat diterapkan, dan orang dengan begitu juga ikut melakukan kegiatan pada suatu penentuan lebih jauh, pembentukan, dari hukum itu. ${ }^{20}$

Ilmu Hukum dapat dipelajari lebih lanjut dengan mengetahui berbagai jenisnya. Jenis-jenis Ilmu Hukum antara lain: ${ }^{21}$

1. Ilmu Hukum Dogmatik.

2. Ilmu Hukum Empirik.

3. Sosiologi Hukum.

4. Sejarah Hukum.

5. Perbandingan Hukum.

6. Psikologi Hukum.

\section{Problematika Ilmu Hukum di Indonesia}

Perkembangan Ilmu Hukum di Indonesia mungkin tidak sepesat perkembangan Ilmu Hukum di negara lain, karena saat ini seolah-olah pendidikan Ilmu Hukum di Indonesia tiba di persimpangan jalan antara Ilmu Hukum yang beraliran Eropa Kontinental dan Anglo Saxon/ Amerika. Walaupun secara prinsip Indonesia mengikuti aliran Eropa Kontinental yang dibawa oleh penjajah Belanda, akan tetapi saat ini aliran Anglo Saxon/ Amerika cukup berpengaruh di Indonesia, terutama melalui bidang ekonomi.

Aliran Eropa Kontinental menitikberatkan pada perkembangan Ilmu Hukum melalui pembuatan peraturan perundang-undangan yang

${ }^{20}$ H.Ph.Visser 't Hooft, Filsafat Ilmu Hukum, diterjemahkan oleh B.Arief Sidharta, Laboratorium Hukum FH Universitas Katolik Parahyangan, Bandung, 2003, hlm.3.

${ }^{21}$ D.H.M.Meuwissen, Pengembanan Hukum, Ilmu Hukum, Teori Hukum dan Filsafat Hukum, diterjemahkan oleh B.Arief Sidharta, tanpa penerbit, Bandung, 2006, hlm.40. 
dilaksanakan oleh kekuasaan legislatif, sedangkan aliran Anglo Amerika menitikberatkan pada perkembangan Ilmu Hukum melalui putusan pengadilan yang dilaksanakan oleh kekuasaan yudikatif. Dengan demikian proses pendidikan Ilmu Hukum di Indonesia akan menyesuaikan dengan aliran Ilmu Hukum yang dianut tersebut. Hal ini merupakan hal yang nyata karena pendidikan Ilmu Hukum akan mengikuti keinginan pangsa pasar yang ada.

Aliran Ilmu Hukum yang berkembang dan dianut di Indonesia juga akan mempengaruhi produk hukum yang dihasilkannya, baik berupa peraturan perundang-undangan, peraturan kebijaksanaan, teori-teori yang dikembangkan oleh pakar hukum di Indonesia, sampai pada putusan-putusan hakim di pengadilan tingkat rendah sampai Mahkamah Agung dan Mahkamah Konstitusi. Kenyataan yang ada pada saat ini, Indonesia masih menitikberatkan pada pembentukan hukum melalui legislatif, yaitu melalui lembaga Dewan Perwakilan Rakyat (DPR) dalam bentuk Undang-undang, sedangkan putusan-putusan pengadilan yang dilakukan oleh para hakim cenderung tidak menyimpang dari peraturan perundang-undangan yang ada (terutama Undang-undang).

Hukum pada dasarnya mengembangkan diri oleh suatu kerjasama yang kompleks antara pembentuk undang-undang, hakim, dan Ilmu Hukum. Pembentuk undang-undang sendiri memberikan kontribusi pada pembentukan pengertian dalam hukum (Ilmu Hukum adalah "seringkali tidak lain daripada kelanjutan dari pembentukan pengertian yang sudah dimulai oleh pembentuk undang-undang itu sendiri"), namun juga selalu mengambil alih pengertian-pengertian dari ilmu dan bekerja dengannya. ${ }^{22}$

Terjadi hubungan yang saling mempengaruhi yang berlangsung terus menerus. Ilmu Hukum menyajikan (menyodorkan) kepada hakim berbagai kemungkinan penyelesaian masalah dan ilmuwan hukum secara konstan menyibukkan diri dengan (mengkaji) putusan-putusan dari hakim, yang dengan itu jalan-jalan baru dikembangkan. Perbedaan antara pembentukan hukum secara ilmiah bidang ilmu hukum (rechtswetenschappelijke rechtsvorming) dan pembentukan hukum oleh hakim seolah-olah terletak pada tataran institusional. ${ }^{23}$

${ }^{22}$ H.Ph.Visser 't Hooft dalam subbab 1.4. mengenai Ilmu Hukum dan hakim; menalar secara yuridikal:, Op.Cit.,hlm.10.

${ }^{23}$ Ibid., hlm.10-11. 
Hakim dalam kerjasama dengan Ilmu Hukum telah menambahkan keseluruhan ajaran-ajaran pada hukum positif yang tidak dapat dikembalikan pada kaidah-kaidah yang dipositifkan (yang dapat dibaca dalam undang-undang) dan penilaian-penilaian yang ada di belakangnya, namun yang merupakan akibat pengambilalihan orientasi-orientasi dari medan kemasyarakatan yang lebih luas. Contoh-contoh tentang hal ini adalah penyalahgunaan hak, perbuatan melanggar hukum oleh penguasa (birokrasi pemerintahan), ganti rugi immaterial, bezitloos pandrecht atau rectsverwerking (pelepasan hak). ${ }^{24}$

Perbedaan dalam penetapan tugas antara peradilan dan Ilmu Hukum juga berarti: komplementaritas, hubungan saling mempengaruhi, dan dengan itu mengandaikan suatu metodik yang sama. Jika tidak begitu halnya maka hubungan saling mempengaruhi itu akan tidak dapat dijelaskan. Orang beroperasi, dalam konteks yang satu atau dalam konteks yang lainnya, dengan jenis betuk-bentuk argumentasi yang sama. Ilmuwan hukum membaca, dalam putusan badan kehakiman (meskipun kadangkadang lewat dugaan-dugaan tentang apa yang telah menggerakkan hakim pada suatu pendirian tertentu), argumen-argumen yang ia olah menjadi lebih produktif atau sebaliknya mengkritiknya; hakim menemukan, dalam kepustakaan ilmiah bidang-ilmu-hukum, argumen yang ia (meskipun kadang-kadang tidak diucapkan) letakkan (gunakan) sebagai landasan putusannya. Medan berkiprah bersama ini mewujudkan wilayah dari apa yang orang akan dapat menyebutnya menalar secara yuridikal (penalaran hukum, juridisch redenering, legal reasoning). Juga istilah "penemuan hukum" banyak digunakan untuk menunjuk wilayah ini. ${ }^{25}$

\section{Filsafat Ilmu sebagai Alat Pengembangan Ilmu}

Filsafat ilmu ialah penyelidikan tentang ciri-ciri pengetahuan ilmiah dan cara-cara untuk memperolehnya. Dengan kata lain, filsafat ilmu sesungguhnya merupakan suatu penyelidikan lanjutan. ${ }^{26}$ Untuk itu filsafat ilmu merupakan secondary reflexion atau suatu bentuk pemikiran secara mendalam yang bersifat lanjutan. ${ }^{27}$

\footnotetext{
${ }^{24}$ Ibid., hlm.11.

${ }^{25}$ Ibid., hlm.12.

${ }^{26}$ Beerling, Kwee, Mooij van Peursen, Op.Cit., hlm.1.

${ }^{27}$ Ibid.
} 
Sumbangan filsafat ilmu sebagai refleksi sekunder ada dua bentuk ${ }^{28}$ :

1. Dapat mengarahkan metode-metode penyelidikan ilmiah kejuruan kepada penyelenggaraan kegiatan-kegiatan ilmiah.

2. Dapat menerapkan penyelidikan kefilsafatan terhadap kegiatan ilmiah.

Filsafat ilmu tidak berhenti pada pertanyaan mengenai bagaimana pertumbuhan serta cara penyelenggaraan ilmu dalam kenyataannya, melainkan persoalan masalah metodologik, yaitu mengenai asas-asas serta alasan apakah yang menyebabkan ilmu dapat mengatakan bahwa ia memperoleh pengetahuan "ilmiah" ${ }^{29}$

Penyelidikan mengenai "cara-cara memperoleh pengetahuan ilmiah" tidaklah bersangkutan dengan proses-proses kejiwaan yang terdapat pada penyelenggara ilmu seorang demi seorang. Juga tidak bersangkutan dengan syarat-syarat lingkungan yang ditentukan lebih lanjut oleh penyelenggaraan ilmu secara umum. Melainkan, bersangkutan dengan susunan logik serta metodologik, urutan serta hubungan antara pelbagai langkah dalam penyelidikan ilmiah. Dan bersangkutan pula dengan susunan logik serta metodologik, urutan serta hubungan antara unsurunsur serta struktur-struktur yang berlaku dalam pemikiran ilmiah. ${ }^{30}$

Hal inilah yang menunjukkan sifat umum dari suatu ilmu atau pengetahuan ilmiah, bahwa sifat-sifat pribadi serta orang seorang yang dipunyai oleh subjek dengan sendirinya tidak relevan. Yang penting, subjek tersebut harus memenuhi sejumlah syarat tertentu: derajat kecerdasan, kemampuan untuk berpikir secara akali dan secara kritik, pengetahuan yang luas mengenai penyusunan pengertian dan teknik-teknik penyelidikan, dan sebagainya. Setiap subjek kalau perlu dapat digantikan kedudukannya oleh sembarang subjek yang lain, yang menilik keadaannya mempunyai pembawaan, perhatian, kecerdasan akal, serta pendidikan pendahuluan. ${ }^{31}$

Di dalam suatu filsafat ilmu biasanya ruang yang disediakan untuk membahas ilmu-ilmu terapan lebih sedikit dibandingkan dengan yang disediakan untuk membahas ilmu-ilmu murni. Tetapi di dalam kenyatannya di lapangan yang dicakup oleh ilmu-ilmu terapan merupakan bagian terbesar dari segenap kegiatan ilmiah. Memang dapat dimengerti

\footnotetext{
${ }^{28}$ Ibid.,hlm.2.

${ }^{29}$ Ibid.

${ }^{30}$ Ibid., hlm.4.

${ }^{31}$ Ibid., hlm.7.
} 
mengapa filsafat ilmu mengutamakan pembahasan ilmu-ilmu formal serta ilmu-ilmu empirik murni. Karena dalam pembahasan tadi senantiasa dikemukakan masalah-masalah yang sama mengenai "eksplikasi”, "definisi", "keajegan", dan sebagainya dalam bentuk yang lebih murni, yang akan muncul kembali bila ilmu-ilmu semacam itu tampil dalam rangka usaha penerapan, misalnya, dalam ilmu-ilmu teknik. Namun ada satu masalah yang pada ilmu-ilmu terapan menampak secara jauh lebih luas, apakah ilmu bersifat bebas-nilai ataukah tidak? Yang demikian ini antara lain berhubungan dengan keadaan bahwa ilmu-ilmu terapan merupakan titik pertemuan yang lebih langsung antara ilmu dengan masyarakat dibandingkan dengan keadaan ilmu-ilmu murni. ${ }^{32}$

Apakah ilmu bersifat "bebas-nilai"?, dapat atau seharusnya bersifat demikian? Hal ini berkaitan dengan gambaran tentang ilmu-ilmu alam yang berbeda dengan ilmu-ilmu manusia. Sesuatu tanggapan disebut pertimbangan nilai (= value judgement) jika di dalamnya orang mengatakan bahwa sesuatu hal baik atau keliru, diharapkan atau tidak diharapkan, positif atau negatif, menguntungkan atau merugikan, indah atau jelek, atau apakah sesuatu hal layak untuk diutamakan dibandingkan dengan hal-hal yang lain.Akan tetapi yang harus diperhatikan adalah perbedaan antara penyelenggaraan ilmu dan penerapan ilmu, antara "mengusahakan ilmu" dengan "melakukan sesuatu dengan menggunakan ilmu" ${ }^{33}$

Contohnya adalah ketika ada definisi tentang demokrasi, yaitu bentuk negara atau bentuk pemerintahan di mana kekuasaan berada di tangan rakyat atau badan perwakilan yang dipilih oleh rakyat, maka hal ini merupakan bagian dari "penyelenggaraan ilmu" yang bersifat "bebas nilai". Akan tetapi ketika seseorang memberikan penjelasan tentang suatu pengertian, yaitu bahwa demokrasi merupakan suatu bentuk negara atau bentuk pemerintahan yang terbaik atau yang paling buruk, maka di sini telah ditetapkan suatu pertimbangan nilai, yang menunjukkan adanya pengambilan sikap atau memilih pihak. Hal terakhir ini merupakan bagian dari penerapan ilmu yang tidak bersifat "bebas nilai". ${ }^{34}$

Tetapi yang tidak dapat diingkari ialah bahwa ilmu-ilmu manusia menimbulkan kesulitan-kesulitan khusus yang bersangkutan dengan

\footnotetext{
${ }^{32}$ Ibid., hlm.142.

${ }^{33}$ Ibid., disarikan dari hlm.132-133.

${ }^{34}$ Ibid.
} 
masalah keadaan-bebas-nilai. Hal ini dikarenakan bahan-bahan atau gejala-gejala yang dihadapi ilmu-ilmu manusia (atau "ilmu-ilmu masyarakat") berbeda dari ilmu-ilmu alam. Apabila memang benar bahwa penyelenggaraan ilmu-ilmu manusia mau tidak mau harus menggunakan kategori-kategori nilai dan memberikan pertimbangan nilai untuk memberikan penjelasan-penjelasan mengenai gejala-gejala yang diselidikinya, maka apakah ini tentu berarti bahwa kategori-kategori nilai serta pertimbangan tersebut senantiasa bersifat "subyektif" serta "semaumaunya" tanpa dapat diubah serta diperbaiki? Apakah tidak mungkin, seperti yang dikatakan F. Kaufmann, dapat ditunjukkan adanya dua jalur yang sejajar antara metodologi dan axiologi (filsafat nilai)? Artinya, bahwa dalam kedua hal tersebut yang menjadi masalah ialah pemilihan dan penentuan yang didasarkan atas aturan-aturan yang secara diam-diam telah diandaikan. Penerapannya dalam hal yang pertama menghasilkan "keyakinan-keyakinan yang lurus" ("correct beliefs"), dan dalam hal yang kedua menghasilkan "pengutamaan-pengutamaan yang lurus" ("correct preferences"), dalam hal yang pertama didasarkan atas "aturan-aturan acara ilmiah", dan dalam hal yang kedua didasarkan atas "aturan-aturan penilaian" ("rules of valuation"). Jika orang berbicara mengenai keadaan bebas-nilai, khususnya dengan mengingat ilmu-ilmu manusia dan hanya memperhatikan "penyelenggaraan secara murni" dari ilmu-ilmu tersebut, maka akan muncul masalah-masalah dari segala penjuru. Apabila bagianbagian penyusun yang mengandung nilai dicabut sampai akar-akarnya, maka akan hilang sifat khusus manusiawinya, yang tidak sekedar mempunyai akibat di bidang teori. ${ }^{35}$

Pertimbangan nilai merupakan pra-anggapan non-ilmiah ilmu terapan, bahkan secara tidak langsung merupakan pra-anggapan segenap ilmu. Tanpa pertimbangan nilai tidaklah mungkin orang melakukan pilihan. Justru bila ilmu terapan tidak membuat pertimbangan nilai, tampak betapa perlunya dilakukan pengolahan secara ilmiah terhadap nilai-nilai. Nilai-nilai dapat menjadi objek penyelidikan dan dapat dilekati oleh sifat yang berasal dari suatu ilmu tertentu. Pertimbangan nilai tidaklah menambah pengetahuan mengenai sesuatu hal, melainkan mungkin sekali menyebabkan adanya pengetahuan yang berjenis lain: pertimbangan tersebut terutama memberikan norma bagi suatu pendekatan. Oleh karena itu pertimbangan nilai acapkali bertalian dengan atau dapat diterjemahkan

\footnotetext{
${ }^{35}$ Ibid., hlm.140-141.
} 
menjadi himbauan untuk bertindak dan mengambil sikap tertentu. Sesungguhnya ilmu-ilmu menggambarkan suatu nilai dalam kebudayaan manusia. Justru karena merupakan nilai maka berusaha sedapat mungkin untuk menanggalkan atau menerjemahkan pertimbangan nilai agar dapat secara objektif, dalam arti dengan jalan yang dapat diawasi secara intersubjektif, memberikan penjelasan serta aturan-aturan. Sesungguhnya ilmu itu sendiri merupakan tindakan manusia yang sudah dikurangi kadar nilainya. ${ }^{36}$

Filsafat ilmu merupakan alat yang tepat untuk mengembangkan ilmuilmu terapan yang menyangkut kehidupan manusia, sehingga ilmu-ilmu kemanusiaan itu dapat mengembangkan diri dan sekaligus mengoreksi diri sesuai perkembangan nilai yang ada dalam masyarakat untuk menuju pada tujuan tertentu melalui metode ilmiah tertentu. Filsafat menjadi aktual, khususnya filsafat ilmu yang kita butuhkan sebagai 'overview' sebagai jaring interaksi, interrelasi dan interdependensi antar cabang ilmu yang satu dengan cabang yang lain, juga dengan filsafat sendiri. ${ }^{37}$

Filsafatlah yang akan mendorong kita pada perluasan wawasan kita, ketajaman refleksi kita, kedalaman imajinasi kita, kepekaan intuisi kita sedemikian rupa agar terhindarlah kita dari simplisme berfikir yang memuakkan, dari 'kerabunan intelektual', hanyut dalam 'arus tradisi ilmu'. Sangat berbahaya apabila kita beranggapan bahwa ilmu merupakan 'barang yang sudah jadi', mandeg-selesai, tertutup bagi perubahan dan pembaharuan. ${ }^{38}$ Usaha untuk mendalami setiap cabang ilmu pengetahuan akan lebih berhasil, apabila usaha itu didasari oleh ajaran-ajaran ilmu filsafat yang ada kaitannya dengan ilmu yang bersangkutan. ${ }^{39}$

${ }^{36} \mathrm{Ibid} .$, hlm.147-149. Seperti juga pendapat dari Koento Wibisono Siswomihardjo, Filsafat Ilmu; Sejarah Kelahiran serta Perkembangannya, dalam M. Thoyibi (Editor), Filsafat Ilmu dan Perkembangannya, Muhammadiyah University Press, Universitas Muhammadiyah Surakarta, Surakarta, 1994, hlm.19. Ilmu sebagai produk adalah bebas nilai. Sedang ilmu sebagai masyarakat, apalagi sebagai proses selalu berada dalam konteks. Hal ini berarti bahwa ilmu selalu terikat oleh nilai. Ilmu sebagai produk pun, apabila sudah diterapkan secara praktis untuk mencapai tujuan, secara implisit sudah dikendalikan oleh nilai.

${ }^{37}$ Koento Wibisono Siswomihardjo, Ibid., hlm.18.

${ }^{38}$ Ibid.

${ }^{39}$ Koento Wibisono Siswomihardjo, Arti Perkembangan Menurut Filsafat Positivisme Auguste Comte, Gadjah Mada University Press, Yogyakarta, 1996, hlm.118. 


\section{Dasar dan Arah Pengembangan Ilmu Hukum di Indonesia}

Ilmu Hukum di Indonesia saat ini sedang mengalami krisis, seolaholah 'hidup segan, mati tak mau'. Padahal, sejarah sains menunjukkan bahwa sepanjang bentangan perjalanan sains ini, Ilmu Hukum telah menjadi salah satu bidang sains yang secara pesat mengaplikasikan metode-metode dalam setiap perkembangannya. ${ }^{40}$

Strategi pengembangan $\mathrm{ilmu} \mathrm{u}^{41}$ yang paling tepat menurut pendapat Koento Wibisono ${ }^{42}$, adalah sebagai berikut:

1. Visi dan orientasi filosofiknyadiletakkan pada nilai-nilai (Pancasila) di dalam menghadapi masalah-masalah yang harus dipecahkan sebagai data/fakta objektif dalam satu kesatuan integratif.

2. Visi dan orientasi operasionalnya diletakkan pada dimensi-dimensi:

a) Teleologis, dalam arti bahwa ilmu pengetahuan hanya sekedar sarana yang memang harus kita pergunakan untuk mencapai suatu teleos (tujuan), yaitu sebagaimana dicantumkan dalam Pembukaan Undang-undang Dasar 1945.

b) Etis, dalam arti bahwa ilmu pengetahuan harus kita operasionalisasikan untuk meningkatkan harkat dan martabat manusia. Manusia harus berada pada tempat yang sentral. Sifat etis ini menuntut penerapan ilmu pengetahuan secara bertanggungjawab.

c) Integral/Integratif, dalam arti bahwa penerapan ilmu pengetahuan untuk meningkatkan kualitas manusia, sekaligus juga diarahkan untuk meningkatkan kualitas struktur masyarakatnya, sebab manusia hidup dalam relasi baik dengan sesama maupun dengan masyarakat yang menjadi ajangnya. Peningkatan kualitas manusia harus terintegrasikan ke dalam masyarakat yang juga harus ditingkatkan kualitas strukturnya.

${ }^{40}$ Lili Rasjidi, Pembangunan Sistem Hukum dalam rangka Pembinaan Hukum Nasional, dalam I Made Widnyana, dkk (Editor), Bunga Rampai Pembangunan Hukum Indonesia, Eresco, Bandung, 1995, hlm.364.

${ }^{41}$ Dalam hal ini adalah Ilmu Hukum.

${ }^{42}$ Koento Wibisono Siswomihardjo, Ilmu Pengetahuan: Kelahiran dan Perkembangannya, Klasifikasi dan Strategi Pengembangannya, dalam M.Thoyibi (Editor), Op.Cit., hlm.62-63. 
Ilmu Hukum dapat dikembangkan melalui objek filsafat ilmu sebagai arah dan dasarnya, karena objek filsafat ilmu, yaitu ontologi, epistemologi dan aksiologi, adalah tiang-tiang penyangga eksistensi ilmu pengetahuan. ${ }^{43}$

Ontologi dalam Ilmu Hukum, adalah untuk menjawab apa hakikat dari hukum. Hukum, sebagaimana telah dibicarakan dalam berbagai literatur dan berbagai teori yang dikemukan oleh para ahli hukum, ternyata tidak ada kesatuan pendapat dalam definisinya. Perbedaan pendapat ini memang merupakan suatu hal yang wajar, karena dengan perbedaan ini akan memberikan peningkatan derajat keilmuan itu sendiri.

Ontologi Hukum pada dasarnya merefleksikan hakikat hukum dan konsep-konsep fundamental dalam hukum, seperti konsep demokrasi, hubungan hukum dan kekuasaan, hubungan hukum dan moral. ${ }^{44}$

Aspek ontologi menyangkut the Knower, yaitu manusia yang bersifat kreatif memiliki kemampuan untuk mengetahui jagat raya beserta isinya, sehingga ia harus mempunyai kesadaran (consciousness). Kesadaran adalah hal yang paling fundamental pada manusia karena akan mempengaruhi persepsi dan terlebih lagi konsepsinya, dimana persepsi dan konsepsi inilah yang disebut pengetahuan. Di dunia ilmu empirikal, kesadaran itu terlahir sebagai paradigma atau pola pikir. Paradigma atau pola pikir itu tidak netral, begitu pula pengetahuan empirik yang dihasilkannya. Kesadaran akan mengisi tiga aspek kemampuan manusia, yaitu kognitif, afektif dan psikomotorik. ${ }^{45}$

Aspek ontologi dalam Ilmu Hukum menyangkut konsep-konsep hukum yang pada dasarnya muncul dari persepsi manusia tentang hukum itu sendiri, dengan demikian konsep hukum di Indonesia akan sangat terkait dengan persepsi manusia Indonesia terhadap hukum. Kesadaran akan Ilmu Hukum di Indonesia akan sangat tergantung pada kemampuan manusia Indonesia dalam tiga aspeknya, yaitu kognitif (rasio/kemampuan untuk mengetahui) yang an sich adalah netral, afektif (rasa/kemampuan untuk merasakan) yang adalah selalu memihak, dan psikomotorik (karsa/ kemampuan untuk gerak) sebagaimana didiktekan oleh rasa/afektif. Ketiga kemampuan itu berpusat pada rasa yang menghubungkan manusia

\footnotetext{
${ }^{43}$ Lihat Koento Wibisono Siswomihardjo, Filsafat Ilmu; Sejarah Kelahiran serta Perkembangannya, dalam M. Thoyibi (Editor), Loc.Cit.

${ }^{44}$ B.Arief Sidharta, "Ilmu..., Op.Cit.,hlm.5.

${ }^{45}$ Disarikan dari Herman Soewardi, Nalar, Kontemplasi dan Realita, Program Pascasarjana Universitas Padjadjaran, Bandung, 1996, hlm. 4-5.
} 
dengan Ilahi. Rasa bertalian erat dengan rasio dan karsa, namun ketiganya mempunyai interdependensi dan fungsi masing-masing. Ketiganya saling mendukung namun tidak saling berbaur. ${ }^{46}$

Ilmu Hukum di Indonesia dapat dikembangkan dengan menetapkan visi dan misi para ahli hukum Indonesia untuk mengarahkan Ilmu Hukum sesuai dengan kesadaran manusia Indonesia atau lebih tepatnya lagi sesuai dengan nilai-nilai yang berkembang dalam masyarakat Indonesia, sehingga Ilmu Hukum di Indonesia dapat berkembang sesuai dengan kemampuan manusia Indonesia, bahkan sesuai dengan kebutuhan Indonesia.

Epistemologi dalam Ilmu Hukum merefleksikan pertanyaan tentang sejauhmana pengetahuan tentang hakikat hukum dan masalah-masalah fundamental dalam filsafat hukum mungkin dijalankan akal budi manusia. ${ }^{47}$

Aspek epistemologi menyangkut the Knowing atau seluk beluk yang bertalian dengan mengetahui, yang berlandaskan pada aspek kognitif/ akali/rasio. Pada dasarnya rasionalitas bersifat netral dengan kemampuan untuk beranalogi (persamaan dan perbedaan) dan berinferensi (deduksi dan induksi). Inilah yang disebut kecerdasan. Rasionalitas yang netral yang melandasi sains empirikal ternyata dapat memunculkan ilmu-ilmu yang tidak netral, karena telah diwarnai oleh nilainilai tertentu. Contohnya sains empirikal Barat yang telah diwarnai oleh persepsi dan konsepsi orang Barat tentang individualisme, sekulerisme, naturalisme dan positivisme, sehingga menimbulkan sains empirikal yang serakah, tak bertuhan, materialistis dan sempit. ${ }^{48}$

Hukum sebagai ilmu pengetahuan dalam menyusun obyek atau bahan ilmunya ke dalam struktur ilmu hukum yang konstruktif dan sistematis, juga menggunakan metode-metode tersebut. Metode Induksi adalah metode berpikir dari yang khusus kepada yang umum, sedangkan metode deduksi bersifat sebaliknya, yaitu metode berpikir dari yang umum kepada yang khusus. Metode positivisme yang dipelopori oleh August Comte berpangkal dari apa yang telah diketahui, yang faktual dan positif serta menolak diluar yang positif termasuk metafisika. Sedangkan metode kontemplatif mengakui metode lain berupa intuisi dan perenungan mengingat keterbatasan indra dan akal. ${ }^{49}$

\footnotetext{
${ }^{46}$ Lihat Herman Soewardi, Ibid., hlm.5-6.

${ }^{47}$ B. Arief Sidharta, "Ilmu..., Loc.Cit.

${ }^{48}$ Herman Soewardi, Op.Cit.,hlm.7-10.

${ }^{49}$ Moch. Fatich, Loc.Cit. Lihat juga Koento Wibisono Siswomihardjo, Arti..., Op.Cit.
} 
Pengembangan Ilmu Hukum di Indonesia seharusnya didasarkan atas rasionalitas yang bersifat transedental, luas dan terbuka, serta lurus dan murni. ${ }^{50}$

Ilmu Hukum di Indonesia akan merupakan ilmu yang dihasilkan dari rasionalitas yang mengakui adanya Tuhan (religius), kekeluargaan atau gotong royong, persatuan, musyawarah untuk mufakat, dan berkeadilan sosial (kemanusiaan). Hal ini sesuai dengan nilai-nilai Pancasila yang berkembang di bumi Indonesia dan secara formal yuridis telah tercantum dalam Pembukaan UUD 1945. Bangsa Indonesia menganut kepercayaan adanya Tuhan Yang Maha Esa, membuka diri untuk bergaul dengan berbagai bangsa tanpa membeda-bedakan golongan baik agama, etnis, jenis kelamin dan sebagainya dengan politik bebas aktif dalam pergaulan dunia, bahkan mengakui bahwa kemerdekaan adalah hak asasi seluruh bangsa akan tetapi akan bersikap tegas dan berjuang sampai titik darah penghabisan apabila kemerdekaan dan kebebasan bangsa Indonesia terancam. Perlindungan atas hak-hak asasi manusia dan khususnya warga negara Indonesia telah dengan jelas dan tegas tercantum dalam batang tubuh UUD 1945 (sampai amandemen keempat). Rasionalitas yang demikian itu akan menghasilkan sains empirikal yang transedental, terbuka bagi perubahan, berkemanusiaan, dan luas.

Aksiologi dalam Ilmu Hukum merefleksikan isi dan nilai-nilai yang termuat dalam hukum seperti kelayakan, persamaan, keadilan, kebebasan, dan kebenaran. ${ }^{51}$ Aspek aksiologi menyangkut the Knowledge, sebagai hasil dari Knowing. Knowing Ilmu Tauhidullah akan menghasilkan pengetahuan (knowledge) Tauhidullah di semua bidang ilmu. ${ }^{52}$

Ilmu Hukum di Indonesia sebagai pengetahuan yang muncul atau hasil dari rasionalitas bangsa Indonesia yang berketuhanan, berperikemanusiaan, berpersatuan, berkerakyatan dan berkeadilan, seharusnya merupakan ilmu hukum yang muncul dengan ciri-ciri tersebut. Ilmu Hukum di Indonesia akan menjadi "panglima" bagi kehidupan berbangsa dan berbangsa, sekaligus menghasilkan produk-produk hukum dan penegak hukum yang didasarkan pada nilai-nilai yang berkembang dalam masyarakat Indonesia.

${ }^{50}$ Herman Soewardi, Op.Cit., hlm.10. Lebih lanjut, ilmu yang demikian itu menurut Herman Soewardi disebut sebagai Ilmu Tauhidullah merupakan epistemologi baru sebagai alternative bagi ilmu Barat sekuler, Ibid., hlm.13.

${ }^{51}$ B.Arief Sidharta, "Ilmu..., Loc.Cit.

${ }^{52}$ Herman Soewardi, Op.Cit., hlm.15. 


\section{Penutup}

Filsafat Ilmu sebagai penyelidikan tentang ciri-ciri pengetahuan ilmiah dan cara-cara untuk memperolehnya merupakan alat yang tepat untuk memberikan arah dan dasar bagi perkembangan Ilmu Hukum di Indonesia.

Aspek-aspek dalam Filsafat Ilmu yang menyangkut ontologi (Knower), epistemologi (Knowing) dan aksiologi (Knowledge), dalam pemahaman terhadap Ilmu Hukum di Indonesia akan mendukung perkembangan Ilmu Hukum di Indonesia ke arah Ilmu Hukum yang berketuhanan, berperikemanusiaan, berpersatuan, berkerakyatan dan berkeadilan.

Para pakar Ilmu Hukum tidak akan lagi terjebak pada pemikiran tentang perkembangan Ilmu Hukum di Indonesia yang beraliran Eropa Kontinental atau Anglo Saxon/Amerika, karena Ilmu Hukum di Indonesia dapat berkembang sesuai dengan eksistensi, rasionalitas dan pengetahuan yang didasarkan oleh nilai-nilai yang dianutnya. Ilmu Hukum di Indonesia akan merupakan Ilmu Hukum dengan karakteristik yang mandiri dan berkembang sesuai dengan kepribadian masyarakat Indonesia, yaitu Pancasila.

\section{Dsftar Pustaka}

Abdurrahman, Ilmu Hukum, Teori Hukum dan Ilmu Perundang-undangan, Citra Aditya Bakti, Bandung, 1995.

Archie J. Bahm, "What is Science (Apa itu Ilmu)", makalah tanpa tahun. B. Arief Sidharta, "Ilmu, Teori dan Filsafat Hukum", bahan kuliah Program Doktor (S-3) Ilmu Hukum, Fakultas Hukum Universitas Islam Indonesia, 2007.

- - , "Posisi Ilmu Hukum dalam Klasifikasi Ilmu”, makalah tanpa tahun.

Beerling, Kwee, Mooij van Peursen, Pengantar Filsafat Ilmu, Cetakan Ketiga, diterjemahkan oleh Soejono Soemargono, Tiara Wacana Yogya, Yogyakarta, 1990.

D.H.M.Meuwissen, Pengembanan Hukum, Ilmu Hukum, Teori Hukum dan Filsafat Hukum, diterjemahkan oleh B.Arief Sidharta, tanpa penerbit, Bandung, 2006.

Esmi Warassih, “Metodologi Penelitian Hukum”, makalah tanpa tahun.

Franz Magnis Suseno, Filsafat sebagai Ilmu Kritis, Cetakan Pertama, Kanisius, Yogyakarta, 1992. 
Herman Soewardi, Nalar, Kontemplasi dan Realita, Program Pascasarjana Universitas Padjadjaran, Bandung, 1996.

H.Ph.Visser 't Hooft, Filsafat Ilmu Hukum, diterjemahkan oleh B.Arief Sidharta, Laboratorium Hukum FH Universitas Katolik Parahyangan, Bandung, 2003.

I Made Widnyana, dkk (Editor), Bunga Rampai Pembangunan Hukum Indonesia, Eresco, Bandung, 1995.

Koento Wibisono Siswomihardjo, Arti Perkembangan Menurut Filsafat Positivisme Auguste Comte, Gadjah Mada University Press, Yogyakarta, 1996.

Lili Rasjidi, Filsafat Hukum; Apakah Hukum itu?, Cetakan Keenam, Remaja Rosdakarya, Bandung, 1993.

-------, dan I.B. Wyasa Putra, Hukum Sebagai Suatu Sistem, Cetakan Pertama, PT.Remaja Rosdakarya, Bandung, 1993.

L.J. van Apeldoorn, Pengantar Ilmu Hukum, Cetakan Keduapuluhenam, Pradnya Paramita, Jakarta, 1996.

M. Thoyibi (Editor), Filsafat Ilmu dan Perkembangannya, Muhammadiyah University Press, Universitas Muhammadiyah Surakarta, Surakarta, 1994.

Theo Huijbers, Filsafat Hukum, Cetakan Kesembilan, Kanisius, Yogyakarta, 2003.

http:/ / fh.unisma.ac.id/index.php?option=com_content\&task=view\&id= $44 \&$ Itemid $=6$ 